\title{
Training study of undergraduate dentistry students in a public institution of Espírito Santo face to medical urgencies/emergencies
}

\author{
Viviane Santos Alves Mutz ${ }^{a}$, Renata Pittella Cançado ${ }^{b}$
}

\begin{abstract}
OBJECTIVE: This study aimed to evaluate the knowledge and confidence of undergraduate dentistry students in clinical stage about emergency situations in a public higher education institution in the state of Espírito Santo, Brazil.

METHODS: This is a cross-sectional descriptive study in which a questionnaire with 12 multiple choice questions was used to evaluate the level of knowledge and confidence of dentistry students. In addition, a long answer question was used in order to describe any previous experience and treatment approaches.

RESULTS: The results showed that almost all undergraduate students perform preliminary evaluation of the patient, including anamnesis (99.28\%) and blood pressure assessment (94.28\%), which are extremely important to avoid emergencies. Among participants, $50.71 \%$ claimed to feel confident on clinical care of patients with systemic conditions, $69.28 \%$ do not feel capable of diagnosing an urgency/emergency during clinical practice and $88.57 \%$ do not feel able to do an intervention if required. Only $20 \%$ of respondents have experienced any emergency situation.

CONCLUSION: There is a clear need of better preparation of undergraduate dentistry students as well as a continuing learning on medical urgencies/emergencies, so that there is a greater knowledge and confidence to choose the correct intervention, whether during undergraduate course or in future as professional career.
\end{abstract}

Key words: Dentistry; Ambulatory Care; Emergencies

\section{Estudo da capacitação dos acadêmicos de odontologia de uma instituição pública do Espírito Santo frente a urgências/emergências médicas}

\section{RESUMO}

OBJETIVO: Este estudo visou avaliar o nível de conhecimento e a segurança dos acadêmicos de Odontologia de uma instituição pública de ensino superior do Espírito Santo, que estão em fase de atendimentos clínicos, quanto às situações emergenciais.

MÉTODOS: Este é um estudo transversal descritivo em que foram aplicados questionários com 12 questões objetivas, para avaliação do nível de conhecimento e segurança, e uma discursiva para a descrição de experiências já vivenciadas e as condutas adotadas.

RESULTADOS: Os resultados apontaram que quase todos os acadêmicos realizam a avaliação prévia do paciente, tais como anamnese $(99,28 \%)$ e aferição de pressão arterial $(94,28 \%)$, etapas importantíssimas para evitar que emergências ocorram. Dos participantes, $50,71 \%$ afirmaram se sentir seguros para atender pacientes comprometidos sistemicamente, $69,28 \%$ não se julgam capazes de diagnosticar uma urgência/emergência durante o atendimento e $88,57 \%$ não se sentem aptos para uma intervenção, caso ocorra. Apenas $20 \%$ dos respondentes já vivenciaram algum episódio emergencial.

CONCLUSÃO: É nítida a necessidade de uma melhor preparação, bem como de uma educação continuada em urgências/emergências médicas para acadêmicos de Odontologia, a fim de que haja maiores conhecimentos e segurança para uma correta intervenção, seja na graduação, seja na vida profissional futura.

Palavras-chaves: Odontologia; Assistência Ambulatorial; Emergências a Dentist, Federal University of Espirito Santo, Vitória, ES, Brazil

${ }^{\mathrm{b}}$ Associate Professor, Federal University of Espírito Santo, Vitória, ES, Brazil 


\section{INTRODUCTION}

The word emergency can be translated into a critical situation, a dangerous event or sudden difficulty [1]. Medical emergencies consist of health impairment with imminent risk to life [2]. Thus, they require immediate providence. Urgencies are characterized as situations that must be solved in the shortest time possible, but can wait for a period of up to two hours, allowing time for planning $[3,4]$. Although and fortunately medical urgency / emergencies situations in dentistry are not common, professionals and undergraduate students face in their daily lives the risk of finding them. When they occur, they must be taken immediately, as they present risks to the health and life of the patient [5].

According to Andrade and Ranali (2002) [1], the increase in the number of elderly people seeking dental treatment, the tendency to prolong the duration of care sessions and advances in medical therapeutics (leading to longer life expectancy) are some of the factors that can contribute to raise the incidence of these episodes. Therefore, it has been observed that diabetic, hypertensive, cardiac, asthmatic, renal, hepatic and other patients are currently regular patients in dental care.

In view of this reality, the evaluation of the general health status and the adoption of preventive measures increase the clinical safety in the care of patients who require special care. The best way to treat a medical emergency is to prevent it $[6,7]$.

In order to identify the patient's general health condition, anamnesis and an adequate medical history must be performed, which is more effective in the form of a verbal interview with the patient, or family member or caregiver in cases of patients unable to respond. Simply completing a form / questionnaire by the patient himself may not reveal all relevant medical information, since in many cases the patient may not interpret systemic diseases, use of certain medications, signs and symptoms relevant to dental practice. At certain times, it is necessary to request an opinion from the patient's doctor to determine the appropriate time for performing certain procedures [8].

In dentistry, medical urgencies / emergencies, in addition to being related to basic pathologies, are also related to the level of anxiety of the patient during dental care, with stress and fear being the main causes [9]. In order to minimize emergencies arising from stress and fear, conditioning techniques and psychological approach are used, and, lastly, drug therapy is reserved, with the use of anxiolytics and / or conscious sedation with nitrous oxide [10].

The main urgency / emergency situations that may occur in dental care are: syncope, moderate allergic reactions, angina pectoris, postural hypotension, convulsions, bronchospasm, hypoglycemia, anaphylactic shock, myocardial infarction, anesthetic overdose and diabetic coma [11].

Effective emergency care requires training in Basic Life Support (BLS), because in more severe situations, such as in cases of cardiorespiratory arrest, fast and correct actions are required, as well as psychological preparation and safety during help. It is necessary to be able to diagnose the emergency situation and sustain the patient's life, following protocols correctly until there is a specialized medical attention. BLS consists of the recognition and immediate correction of the failure of respiratory and / or cardiovascular systems, evaluating and keeping the victim breathing, with heart beat and without any further complications [9].

It is also necessary to take into account the fact that, in addition to the health condition of patients, the dentist must be concerned with the legal implications that urgencies / emergencies can generate [6]. Law 5081, article 6, item VIII, regulates the professional's performance in emergency situations, giving him the task of "prescribing and applying emergency medication in the case of serious accidents that compromise patient's the life and health". There is no distinction between specialists and clinicians, making clear the responsibility of the entire professional category through this type of situation.

Even in view of the importance of this issue, dental practice has shown that undergraduate students and dentists rarely feel empowered and safe to attend medical emergencies / urgencies in university outpatient clinics and dental offices, respectively. In view of this reality, the present study aimed to investigate the levels of education and safety of undergraduate dentistry students at a public university in the state of Espírito Santo, facing possible emergency eventualities in the academic context, according to the personal perception and experience of each, collected through questionnaires.

\section{METHODS}

This study was a traditional, quantitative and descriptive epidemiological survey. Prior to the beginning of the research, the study was submitted to the Ethics Research Committee of the Center for Health Sciences, Federal University of Espírito Santo and approved under protocol No. 1.208.806.

A questionnaire containing 13 questions, of which 12 were for the evaluation of the level of knowledge and safety and 1 for the description of experienced emergencies, was applied to a group composed of 140 undergraduate Dentistry students of the Federal University of Espírito Santo (of a total of approximate 155 enrolled students), who were in clinical phase, namely, those in the $5^{\text {th }}$ to $10^{\text {th }}$ periods. An informed consent form was delivered, guaranteeing the confidentiality of participants.

After obtaining data, they were tabulated in "Microsoft Office Excel ${ }^{\circledR}$ " spreadsheets and evaluated through statistical analysis, based on central trend measures (mean and percentage).

\section{RESULTS}

In order to know the health profile of patients, $99.28 \%$ (139) of participants carry out anamnesis, 95\% (133) ask the 
main complaint and 95\% (133) describe the medical history. In addition, $87.14 \%$ (122) evaluated the vital signs, $83.57 \%$ (117) performed physical examination.

Almost all participants performed blood pressure (BP) measurement prior to dental procedures, $94.28 \%$ (132) of those who measured BP and 5.7 (8) who did not. The frequency with which they perform it is represented in Figure 1, where $10.60 \%$ did not respond and $5.33 \%$ gave inconsistent answers in this topic.

The safety they feel when attending patients with systemic conditions, such as hypertension, diabetics, cardiac, hepatopathic and other disorders, was questioned by almost half of participants (Figure 2).

Most undergraduate students are not aware if there is or there is not equipment and medication support that can be used in emergencies / emergencies at the University's outpatient clinics (Figure 2).

The majority of participants also do not consider themselves capable of diagnosing a medical urgency / emergency that may occur during clinical care (Figure 2).

Regarding feeling safe to intervene in cases of medical emergencies / urgencies during outpatient care, most of them do not consider themselves able for intervention (Figure 2). In the analysis by period, students with the highest level of security for intervention were those enrolled in the $5^{\text {th }}$ period $(40 \%)$ and the most insecure were those enrolled in the $9^{\text {th }}$ period, with $100 \%$ insecurity.

In all periods, there were participants who had experienced a medical emergency / urgency episode in outpatient clinical care. Of them, $20 \%$ (28) have experienced emergency episode and 80\% (112) have never experienced such a situation. Of these 28 students, $50 \%$ (14) felt safe to practice the emergency procedure and $50 \%$ (14) did not feel safe to do it. Students with the highest number of emergency / urgency reports were those enrolled in the $10^{\text {th }}$ period, with a total of 10 cases reported. Of the 10 students who have experienced this situation, $6(60 \%)$ felt safe to practice the emergency procedure, while the other $40 \%$ (4) did not feel safe.

Of the 28 cases reported, the most common were lipothymia, syncope, hemorrhage, allergic reaction and hypertensive crisis. (Figure 3)

The main methods of control anxiety in patients used in the clinical practice of participants was conversation with the intention of distraction, practiced by $96.42 \%$ (135) of students, $72.85 \%$ (102) avoid unnecessary noise, since they have potential for stress and fear, verbal affirmations as a means of controlling anxiety were performed by $71.42 \%$ (100) and $22.85 \%$ (32) use anxiolytics when necessary.

Although the institution does not have a specific discipline to guide medical emergencies / urgencies in dentistry, $77.14 \%$ (108) reported that they were instructed in other disciplines, such as Oral and Maxillofacial Surgery, Stomatology, Pharmacology, Hospital Dentistry and private course (outside institution). About 17.14\% (24) of students reported that they did not receive instructions in other disciplines.
Participants also recognize the need for better personal improvement in certain disciplines of the curriculum structure of the course, which would provide them with greater security in emergency behaviors. The majority, $56.42 \%$ (79), affirm that they need improvements in Maxillofacial Surgery, a discipline that gives a greater focus on this subject in the $5^{\text {th }}$ period. But $45.71 \%$ (64) reported the need for better knowledge in Pharmacology Applied to Dentistry and $32.14 \%$ (45) in Pharmacy and Therapeutics (General Pharmacology).

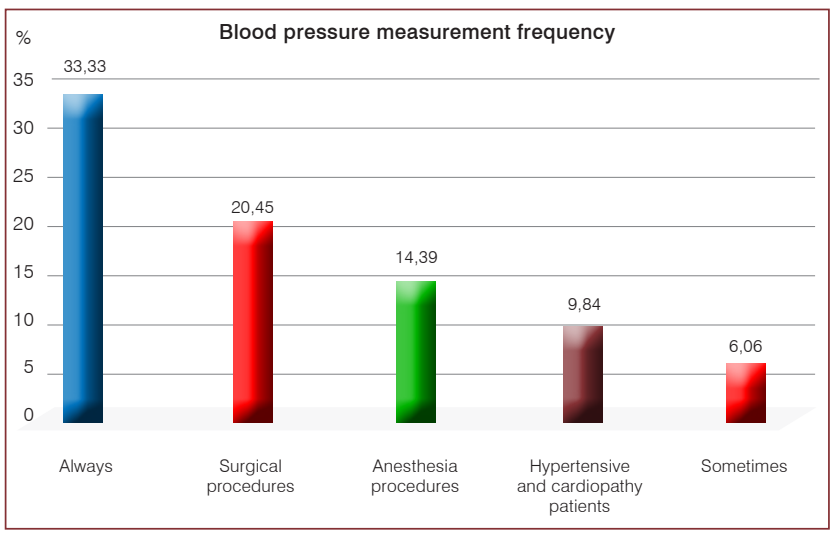

Figure 1. Representation of the frequency with which participants perform blood pressure measurement prior to treatment

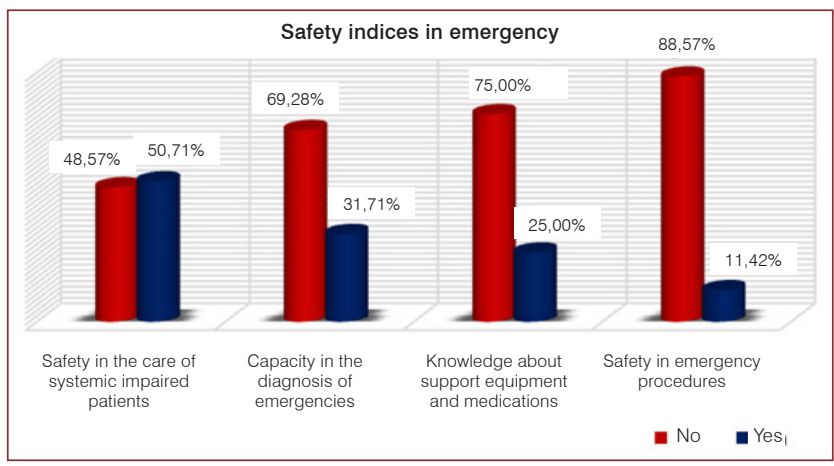

Figure 2. Safety indices in medical emergencies of undergraduate Dentistry students

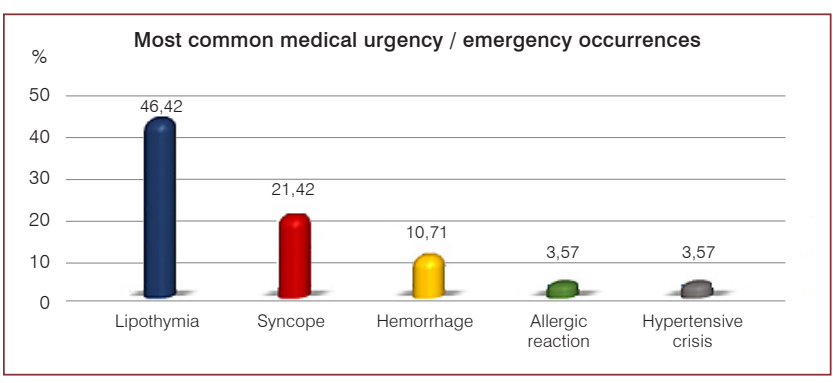

Figure 3. Main occurrences of medical urgencies / emergencies in dental care reported by participants 


\section{DISCUSSION}

In order to avoid medical emergencies / urgencies in dental patients, the early diagnosis of systemic conditions is of paramount importance. Therefore, anamnesis should not be neglected, because it is through it that pathologies relevant to dental treatment are identified [13]. In addition to the diagnosis, anamnesis is important to reveal unpleasant situations experienced by the patient in previous treatments in order to avoid recurrences [1]. Generally, anamnesis includes the main complaint, which represents the fundamental reason that led the patient to consultation, and the description of the medical history, which allows the identification of systemic conditions. These items are completely relevant so that the profile of the patient in care is known [1]. Therefore, the results of this study of $99.28 \%$ for anamnesis, $95 \%$ for the main complaint and $95 \%$ for the description of the medical history, are satisfactorily in line with the recommended protocol. The results of vital signs evaluation were within an acceptable range of achievements (which is the evaluation of the frequency / cardiac rhythm, respiratory rate and blood pressure), corresponding to $87.14 \%$, and physical examination (inspection, palpation, percussion, auscultation and smell), represented by $83.57 \%$.

For Ferraz (2007) [14], blood pressure measurement should be performed in all new patients and in all return visits, since the detection of patients with undiagnosed and uncontrolled hypertension is of extreme importance in order to avoid or minimize complications. This study showed that, to a large extent, students are aware of this relevance, since $94.28 \%$ of them carry out blood pressure measurement. However, although most participants reported the practice of blood pressure measurement, as far as frequency is concerned, only $33.33 \%$ always do this procedure, $20.45 \%$ do it only in case of surgical procedures, $14.39 \%$ in procedures that require anesthesia and $9.84 \%$ only in hypertensive and cardiopathy patients. Low frequency of this procedure makes dental care less safe, increasing the risk of emergencies.

The insecurity of participants was evident from the moment they were questioned about the care given to patients with systemic conditions (hypertensive, diabetic, cardiac, hepatopathic, etc), since almost half of them $(48.57 \%-68)$ do not feel safe to attend patients with this profile. Another relevant point was that the majority of students, represented by $69.28 \%$ (97), do not consider themselves capable of diagnosing the cause of an emergency / urgency situation that may occur during care. This result is similar to that obtained in a study carried out by Caputo (2010) [6], in Ribeirão Preto, State of São Paulo, in which $61.5 \%$ of dentists were unsafe to diagnose a medical emergency in their clinical practice.

In addition, 75\% (105) of undergraduate students are not aware if there is or there is not support equipment and medication that can be used in emergencies / urgencies in the University's outpatient clinics, a result that proves the lack of knowledge of undergraduate students about the support offered by their own educational institution. Therefore, it is concluded that if students do not have the security to attend systemically compromised patients, do not consider themselves capable of diagnosing emergencies and are not aware of the support material offered by the institution, it is expected that they do not feel able and safe to solve such a situation. The majority of participants, represented by $88.57 \%$, do not feel able to intervene in an emergency event. In the individual analysis, students with the highest level of safety for intervention were controversially those enrolled in the $5^{\text {th }}$ period $(40 \%)$ and the most insecure were those enrolled in the $9^{\text {th }}$ period, with $100 \%$ insecurity. This result contrasts the results found in a study conducted in the state of Paraíba by Queiroga (2012) [11], in which beginning students, such as those the $5^{\text {th }}$ period, felt less secure $(29.7 \%)$ and those in $9^{\text {th }}$ period obtained the highest levels of security $(54.5 \%)$. Our result could possibly be explained by the short time in which classes on medical emergencies / urgencies had been taught to students in the $5^{\text {th }}$ period in the Maxillofacial Surgery discipline, giving a feeling of greater safety to students entering the clinical life.

Although in a small number of cases, there were reports of emergency events in all classes, which corroborate the literature that even if they are rare, medical emergencies can occur in dental practice in an unpredictable way, without obeying rules or defined standards [5]. Of all participants (140), only $20 \%$ (28) have experienced medical emergencies / urgencies. Of these, $50 \%$ felt secure in putting some emergency procedure into practice, which can probably be explained by the availability of help from teachers present at the site. Students enrolled in the $10^{\text {th }}$ period had the highest number of cases, which is probably justified by a larger number of patients attended during the course, in addition to the fact that this class, in particular, had at the time of the study, a larger number of students enrolled than the others.

Lipothymia, syncope, hemorrhage, allergic reaction and hypertensive crisis were the most frequent occurrences reported. Lipothymia and syncope occurred more frequently, $46.42 \%$ and $21.42 \%$, respectively. Lipothymia is characterized by a passing discomfort and an agonizing sensation of fainting, which rarely leads to total loss of consciousness and may be called pre-syncope [1]. Syncope, however, is the temporary and momentary loss of consciousness due to cerebral hypoxia as a consequence of a decrease in blood flow to the brain, often accompanied by pallor, hypotension and tachycardia [15]. These urgencies/ emergencies are in agreement with other studies and with literature, which show that lipothymia and syncope constitute the majority of emergency events in dental care [5, 6, 16-18].

For Malamed (2003) [19], the fear of a dentist exists, is always present, and is a source of increased anxiety. This can lead to stress and change the clinical status of the patient, eventually increasing the number of occurrences of medical emergencies. Talking with the patient and explaining the stages of treatment, that is, performing verbal reassurance can avoid adverse events [16]. However, in some cases, 
only psychological conditioning is not sufficient to reduce anxiety, requiring the use of pharmacological methods of conscious sedation $[7,20]$. In this study, it was found that the majority, $96.42 \%$ of students, used conversation as a non-pharmacological means of controlling the anxiety of their patients, reserving the use of anxiolytics $(22.85 \%)$ for special cases.

Until the end of this study, the institution did not offer a specific discipline of guidance to medical emergencies / urgencies. This reality is very common in the country, and there is still a deficit in relation to the teaching of medical emergencies in most dentistry schools. There is no adequate training for this type of situation or incentive for continued learning, and the habit of performing the procedure over and over again results in greater possibilities for success [21].

However, most participants $(77.14 \%)$ reported being instructed in other disciplines, especially in the Maxillofacial Surgery discipline. This fact, added to the low occurrence of emergency events, makes students to have few opportunities to correctly assimilate the procedure [22], giving them great insecurity, which will last during their professional life, if not continuously instructed.

Health care courses need to develop strategies to guide professionals and students how to appropriately behave and act in case of emergencies [23]. Thus, as proposed by Marchini (2000) [24], it is necessary to establish a specific discipline to guide medical urgencies / emergencies, which includes the teaching of emergency measures to maintain life. Seminars, clinical case discussions, lectures and courses with the presence of paramedics and members of the fire brigade and the use of mannequins for practice can be used as teaching strategies. However, in addition to this discipline, periodic maintenance of the knowledge acquired throughout the professional life is necessary [25]. According to the American Heart Association (2015) [26], re-qualification cycles every two years are no longer ideal. More frequent training is needed for professionals who are more likely to find emergency situations, such as dentists [26].

It is also worth mentioning that the existence of a special discipline of medical urgencies / emergencies in educational institutions does not exempt the students' responsibility to seek more in-depth studies, especially disciplines that support them in these cases. The study population recognized this need, mainly in Maxillofacial Surgery (56.42\%).

As this study evaluated the knowledge and the level of safety of students through their perception and personal experience, it is valid to carry out in the future a complementary study with more specific questions about medical urgencies / emergencies that allow evaluating the real knowledge of students and then to compare the results of both studies.

\section{CONCLUSION}

Medical Urgencies / Emergencies in Dentistry are a subject that still provides insecurity in undergraduate students and professionals. The lack of knowledge and / or the sporadic nature of these events are some reasons that provide such insecurity. The present study showed that most students consider themselves insufficiently educated about the subject and have low level of safety for the diagnosis and intervention in emergency situations. Thus, it is necessary to have a better theoretical-practical preparation during the dentistry course and, in the course of professional life, continuing education, so that the correct behaviors are always remembered and that there is security to intervene in eventual emergency situations, either as undergraduate student as in the professional life.

\section{REFERENCES}

1. Andrade ED, Ranali J. Emergências médicas em odontologia. Medidas preventivas, protocolos de pronto atendimento, equipamentos de emergência. São Paulo: Artes Médicas. 2002

2. Lúcio PSC, Barreto RC. Emergências médicas no consultório odontológico e a (in)segurança dos Profissionais. Revista Brasileira de Ciências da Saúde. 2012;16(2):267-72 https://doi.org/10.4034/RBCS.2012. 16.02.23

3. Hanna LMO, Alcântara HSC, Damasceno JM, Santos MTBR. Conhecimento dos cirurgiões dentistas diante de urgência/emergência médica. Rev. Cir Traumatol. Buco-Maxilo-Fac. 2014;14(2):79-86.

4. Silva EL. Avaliação do nível de conhecimento do uso de protocolos de urgência e/ou emergência médica na clínica odontológica [Dissertação]. Belém (PA): Universidade Federal do Pará. De 2006

5. Santos JC, Rumel D. Emergência médica na prática odontológica no Estado de Santa Catarina: ocorrência, equipamentos e drogas, conhecimento e treinamento dos cirurgiões-dentistas. Cien Saude Colet. 2006; 11(1): 183-190. https://doi.org/10.1590/S1413-81232006000100027

6. Caputo IGC, Bazzo GJ, Silva RHA, Júnior ED. Vidas em risco: emergências médicas em consultório odontológico. Rev Cir Traumatol Buco-MaxiloFac. 2010;10(3):51-8

7. Pimentel ACSB, Cappai A, Junior JRF, Grossmann SMC, Magalhães SR Emergências em odontologia: revisão de literatura. Revista de Iniciação Científica da Universidade Vale do Rio Verde. 2014;4(1):105-13.

8. Jolly DE. Evaluation of the medical history. Anesth Prog 1995;42:84-9.

9. Colet D, Griza GL, Fleig CN, Conci RA, Sinegalia AC. Acadêmicos e profissionais da odontologia estão preparados para salvar vidas? RFO UPF. 2011;16(1):25-9.

10 Giorgi MS, Laurindo BN, Frias AC, Santos CMS, Trindade I. Contribuição da homeopatia no controle da ansiedade e do medo como prevenção das emergências médicas em odontologia: estudo piloto. Rev Homeopatia. 2010;73(3/4):17-22

11. Queiroga TB, Gomes RC, Novaes MM, Marques JLS, Santos KSA, Grempel RG. Situações de emergências médicas em consultório odontológico. Avaliação das tomadas de decisões. Rev Cir Traumatol Buco-Maxilo-Fac. 2012;12(1):115-22.

12. Brasil. Lei n. 5.081, de 24 de agosto de 1966. Regula o exercício da odontologia. Diário Oficial da União. 26 ago 1966.

13. Oliveira MMMB, Cerqueira A, Freitas VS, Freitas MA. Prevalência de indivíduos portadores de doenças de base numa clínica de extensão em cirurgia bucal: estudo preliminar. Stomatos. 2006;12(22):35-41.

14. Ferraz EG, Carvalho CM, Jesuíno AA, Provedel L, Sarmento VA. Avaliação da variação da pressão arterial durante o procedimento cirúrgico odontológico. Rev Odontol UNESP. 2007;36(3):223-9.

15. Maringoni RL. Principais emergências médicas no consultório odontológico. Rev Assoc Paul Cir Dent. 1998;52(5):388-96.

16. Guimarães, PSP. Emergências médicas em odontologia. Rev Bras Odontol. 2001;58(5):294-5.

17. Veiga D, Oliveira R, Carvalho J, Mourão J. Emergências médicas em medicina dentária: prevalência e experiência dos médicos dentistas. Rev Port Estomatol Cir Maxilofac. 2012;53(2):77-82. https://doi.org/10.1016/j. rpemd.2012.01.001

18. Sá Del Fiol F, Fernandes A V. Emergências médicas em consultório odontológico. Rev ABO Nac. 2004;12(5):315-8.

19. Malamed SF. Emergency medicine in pediatric dentistry: preparation and management. Journal of the California Dental Association. 2003; $31(10): 749-55$ 
20. Andrade ED. Terapêutica medicamentosa em odontologia. Procedimentos clínicos e uso de medicamentos nas principais situações da prática odontológica. 2a ed. São Paulo: Artes Médicas; 2006.

21. Gaujac C, Oliveira AN, Barreto FAM, Salgado LM, Oliveira MS, Girão RS Reações alérgicas medicamentosas no consultório odontológico. Rev Odontol Univ São Paulo. 2009;21(3):268-76.

22. Silva EL. Alunos formandos e profissionais de odontologia estão capacitados para reconhecerem situações em emergência médica e utilizarem protocolos de atendimento? Arq Odontol. 2006;42(4):257-336.

23. Bordignon MV, Vieira RR, Silva SO, Linden MSS, Trentin MS, De Carli JC Emergências médicas na prática odontológica: ocorrência, equipamentos e drogas, conhecimento dos cirurgiões dentistas do Rio Grande do Sul, Salusvita. 2013;32(2):175-85.
24. Marchini L, Patrocínio MC, Rode SM. Plano de ensino de uma disciplina de "urgências e emergências em Odontologia". PGR: Pós-Grad Rev Fac Odontol São José dos Campos. 2000;3(1):105-12.

25. Marzola C, Griza GL. Profissionais e alunos de odontologia estão aptos para salvar vidas? [Monografia]. Bauru (SP): Associação Paulista dos Cirurgiões Dentistas. 1998.

26. Destaques da American Heart Association 2015. Atualização das diretrizes de RCP e ACE. [Acesso em 13 de junho d 2016]. https://eccguidelines. heart.org/index.php/circulation/cpr-ecc-guidelines-2/ 